\title{
Manajemen komunikasi museum dan pengaruhnya pada kepuasan pengunjung museum sejarah di Bandung
}

\author{
Imam Nuraryo \\ Institut Bisnis dan Informatika Kwik Kian Gie, Jakarta, Indonesia
}

\begin{abstract}
ABSTRAK
Museum tidak lagi dipandang sebagai sebuah tempat untuk menyimpan benda-benda kuno, yang berkait dengan budaya. Museum juga merupakan sarana yang mengkomunikasikan dan menginformasikan sejarah dan perkembangan ekonomi, politik, serta sosial kemasyarakatan. Tujuan penelitian ini adalah untuk mengetahui seberapa besar pengaruh manajemen komunikasi yang terdiri dari memberi layanan informasi nilai kebangsaan, memelihara komunikasi yang baik antara petugas dan pengunjung museum, dan melaksanakan etiket dan tata krama dalam melayani pengunjung museum terhadap kepuasan para pengunjung pada salah satu museum sejarah perjuangan di Kota Bandung. Konsep yang digunakan dalam penelitian ini adalah tiga fungsi relasi publik dari Bertrand R Canfield. Metode penelitian yang digunakan adalah survey eksplanatori. Sampel sebanyak 150 orang, dipilih dari para pengunjung yang datang ke museum pada pertengahan Agustus 2019. Hasil penelitian ini menunjukkan bahwa manajemen komunikasi museum yang terdiri dari memberi layanan informasi nilai-nilai kebangsaan dan sejarah kepada pengunjung museum, memelihara komunikasi yang baik antara petugas dan pengunjung museum, dan melaksanakan etiket dan tata krama dalam melayani pengunjung museum berpengaruh terhadap kepuasan pengunjung. Kesimpulan dari penelitian ini adalah bahwa pada periode penelitian, kegiatan manajemen komunikasi yang dilakukan oleh museum sudah memberikan kepuasan bagi para pengunjungnya. Selain mempertahankan fungsi museum yaitu memberikan pengetahuan kepada pengunjung, pihak museum disarankan harus mempertahankan sikap santun, keramahtamahan, dan kejujuran terhadap pengunjung.
\end{abstract}

Kata-kata kunci: layanan; museum; sejarah; kepuasan; pengunjung

\section{Communication management of historical museum in Bandung and its influence on the visitor satisfaction}

\begin{abstract}
Museum is not only viewed as a place where displayed the ancient artefacts with regards to cultural things, but also a place where we are able to communicate and to inform history and the development of economy, politics and social circumstances. The purpose of this study was to determine how much influence the management of communication consisting of providing information on national and historical values, maintaining good communication between officers and visitors of the museum, and implementing the etiquette and manners to the museum's visitors satisfaction. The concept used in this study is the three functions of public relations from Bertrand $R$ Canfield.. The research method used was an explanatory survey. Samples, 150 respondents, are the visitors who come to the museum in the middle of August 2019. The results of this study indicate that communication management consisting of providing information on national and historical values to museum visitors, maintaining good communication between officers and visitors of the museum, and implementing etiquette and manners in serving museum visitors affect the satisfaction of visitors. In addition to maintaining the function of the museum which is to provide knowledge to visitors, the museum is advised to maintain a good attitude such as politeness, friendliness, and honesty.
\end{abstract}

Keywords : service; museum; history; visitor; satisfaction

Korespondensi: Dr. Imam Nuraryo, M.A. (Comms). Institut Bisnis dan Informatika Kwik Kian Gie. Jln Yos Sudarso kav 87 Sunter, Jakarta 14350.Email : imam@kwikkiangie.ac.id 


\section{PENDAHULUAN}

Kota Bandung dikenal sebagai kota pariwisata yang cukup terkenal sejak dahulu di Nusantara. Selain itu, Kota Bandung juga dikenal sebagai kota perjuangan, di mana sejarah mencatat bahwa para pejuang untuk merebut dan mempertahankan kemerdekaan. Sebagai kota perjuangan, tentunya Bandung ingin dikenang oleh para penduduk beserta anak-cucunya sebagai kota yang sarat akan nilai-nilai patriotik dan nasionalisme. Oleh karena itu, warisan nilai-nilai historis dan kultural ini diupayakan untuk dapat dilestarikan salah satunya dengan mendirikan museum.

Museum merupakan wahana atau arena yang tepat dalam pengembangan budaya. Museum tidak lagi dipandang sebagai sebuah tempat untuk menyimpan bendabenda kuno, yang berkait dengan budaya, tetapi museum juga merupakan sarana yang mengkomunikasikan dan menginformasikan sejarah dan perkembangan ekonomi, politik serta sosial kemasyarakatan. Museum juga memiliki peran strategis di dalam memperkuat identitas masyarakat dan bagian dari pranata sosial yang bertujuan untuk memberikan pendidikan dan penerangan mengenai alam sekitar dan peradaban manusia kepada generasi satu ke generasi berikutnya (Fitriani, 2018).

Kota Bandung mempunyai beberapa museum diantaranya adalah Museum Negeri Sri Baduga, Museum Geologi, Museum Konferensi Asia Afrika, Museum Pos Indonesia, dan Museum Mandala Wangsit Siliwangi (Fuadona, 2016). Museum terbaru yang baru didirikan adalah Museum Kota Bandung yang didirikan tepat di belakang Kantor Walikota Kota Bandung.

Menurut pengamatan peneliti jumlah pengunjung museum di Kota Bandung masih relatif kurang, museum belum menjadi daya tarik utama bagi wisatawan atau masyarakat Kota Bandung khususnya sebagai objek wisata yang menarik untuk dikunjungi. Citra museum yang kuno, penuh dengan arca dan etalase yang memajang barang-barang kuno, lembab, tertinggal jaman, dan menyeramkan masih tersimpan dan bertahan dalam memori sebagian besar masyarakat. Museum belum menjadi tempat yang nyaman sebagai media pendidikan dan hiburan yang menyenangkan.

Salah satu strategi yang bisa digunakan untuk mampu mengundang keingintahuan warga adalah dengan memodifikasi citra dan bentuk museum sesuai dengan kebutuhan zaman, dengan kata lain bisa memenuhi selera masyarakat zaman sekarang. Para pengelola dan pemerhati museum harus mampu menciptakan ruang bagi pengunjung untuk beraktivitas secara interaktif dan atraktif sehingga menimbulkan ikatan emosi antara museum dan masyarakat. 
Museum sejatinya memberikan apa yang diperlukan masyarakat dan menjawab apa yang menjadi pemikiran masyarakat. Masyarakat tidak lagi harus menyesuaikan diri dengan keberadaan museum yang melekat dengan citra kunonya, tetapi museumlah yang menyesuaikan diri dengan keinginan dan harapan masyarakat. Museum haruslah mengikuti perkembangan zaman dan selalu mereformasi diri sehingga tidak dianggap ketinggalan jaman. Untuk itulah strategi marketing modernpun juga dapat diadopsi untuk mempromosikan museum

In comparison with goods, service offerings have naturally more potential to offer memorable experiences. So, museums, as being a part of the service sector, can create memorable positive experiences for their visitors using experiential marketing strategies as competitive tools (Dirsehan, 2012).

Walaupun museum masih dianggap menjadi tempat mengoleksi barang-barang kuno, museum harus dapat mengejawantahkan kekunoan tersebut dengan cara-cara yang lebih kekinian. Perlu diperhatikan bahwa bendabenda sejarah itu adalah milik jamannya dan tentu ditulis atau ada sesuai dengan kebutuhan jamannya.

Oleh karenaitu, ketika dihadirkan pada masa kini, benda-benda sejarah itu seharusnya dapat dikelola secara kreatif sehingga sesuai dengan pola pikir jaman digital. Namun demikian, esensi yang diusung oleh museum tidak boleh dihilangkan. Melalui metode tersebut, museum akan lebih memiliki jiwa yang dengan sendirinya mampu menyampaikan pesan tertentu kepada setiap pengunjung. Museum sebagai lembaga penyedia jasa informasi wisata sejarah juga harus mampu menarik perhatian khalayak yang menjadi calon pengunjung (Chiappa, Giacomo, Andreu, \& G. Gallarza, 2014).

Canfield dalam bukunya "Public Relations Principles and Problems" menjelaskan secara lebih luas mengenai fungsi dari public relations ini dengan tidak memandang apakah kegiatan public relations itu bersifat internal maupun eksternal. Dalam bukunya, Chanfield mengemukakan tiga fungsi public relations yakni, mengabdi kepada kepentingan umum (it should serve the public's interest), memelihara komunikasi yang baik (maintain good communication) dan menitikberatkan moral dan tingkah laku (stressing good morals and manners) (Effendy, 2009).

Ketiga fungsi tersebut sejatinya dapat diterapkan di dalam pengelolaan komunikasi organisasi. Mengabdi kepada kepentingan umum dapat diartikan sebagai memberikan layanan informasi yang diperlukan oleh pelanggan. Memelihara komunikasi yang baik dalam sebuah organisasi dimaknai sebagai perilaku komunikasi layanan yang baik antara penjual dan pembeli. Menitikberatkan 
moral dan tingkah laku bermakna bagaimana menerapkan etiket dan etika yang baik dalam melayani pelanggan.

Manajer komunikasi, baik itu adalah seorang humas atau staf komunikasi korporat adalah perantara antara pimpinan organisasi dengan publik, baik publik internal atau publik eksternal. Publik mengetahui rencana kebijaksanaan dan usaha-usaha pimpinan organisasi dari divisi yang bertanggung jawab dengan proses komunikasi dalam organisasi tersebut. Oleh karena itu, itu pimpinan organisasi menyempurnakan rencananya, melakukan kebijaksanaannya dan meningkatkan usahausahanya berdasarkan keadaan, situasi, harapan, keinginan publik, baik internal maupun eksternal (Effendy, 2009).

Kondisi tersebut perlu diketahui oleh manajer serta stafnya berkat laporan staf komunikasi korporat atau humas sebagai hasil penyelidikannya. Kegiatan yang "two way traffic" itulah yang menjadi ciri khas aktivitas komunikasi dalam organisasi. Kegiatan manajemen puncak ke publik dan dari publik ke manajemen puncak. Di samping itu, perlu juga memperhatikan aktivitas komunikasi formal maupun informal dalam organisasi.

Dalam pelaksanaannya seorang manajer melakukan banyak komunikasi, baik komunikasi langsung secara personal atau pun komunikasi melalui media massa. Untuk melaksanakan komunikasi dan dalam rangka melayani publik, manajer komunikasi dan para petugasnya, biasanya menempati ruangan yang letaknya strategis sebagai kantornya. Ini untuk memudahkan komunikasi, selain komunikasi vertikal dan horizontal juga komunikasi eksternal.

Salah satu tugas manajer komunikasi di perusahaan ialah sebagai sumber informasi dan saluran informasi. Untuk itu manajer komunikasi mengadakan sebuah information desk untuk melayani publik, baik karyawan maupun orang-orang luar. Untuk petugas pada information desk perlu ditempatkan orangorang yang selain wajahnya menarik dan sikapnya yang ramah, juga harus menguasai berbagai persoalan yang berhubungan dengan organisasi. Ia harus mengetahui sejarah dan perkembangan organisasi, nama-nama pimpinannya, hubungannya dengan berbagai pihak di luar perusahaan, dan lain sebagainya.

Jika ia tidak bisa memberikan informasi kepada publik yang datang memintanya, ia harus bisa menunjukkan kepada orang yang bisa memenuhi kebutuhan informasinya. Intinya adalah manajer komunikasi harus memberikan kepuasan kepada setiap orang yang datang di information desk itu (Effendy, 2009).

Seperti telah dijelaskan juga di atas, kegiatan seorang manajer komunikasi bukan hanya memberikan penerangan. Penerangan 
hanya salah satu bagian kecil dari kegiatan manajerial komunikasi dalam organisasi. Kegiatan penerangan bersifat "one way traffic" hanya searah saja dari pimpinan organisasi ke publik. Sedang kegiatan manajemen komunikasi bersifat "two way traffic" dua arah timbal balik.

Bukan dari organisasi ke publik saja, tetapi saja dari publik ke organisasi. Manajer komunikasi harus bersikap seperti karyawan, harus mempunyai “nose for news". Manajer harus senantiasa mencari berita di kalangan para karyawan, para pemegang saham, supplier, dealer, pelanggan lain dan lain sebagainya yang ada sangkut pautnya dengan organisasinya, untuk kemudian dilaporkan kepada manajer dan stafnya, guna dipakai bahan perencanaan dan kebijaksanaan.

Dalam penelitian ini dilakukan analisis kaitanantaramanajemenkomunikasidankualitas layanan atau jasa. Jasa memiliki karakteristik yang sangat mempengaruhi perencanaan program pemasarannya tersendiri. Tjiptono (Tjiptono, 2014) menyatakan lima karakteristik utama pada jasa yang membedakannya dengan barang. Kelima karakteristik itu yaitu (1) intangibility atau tidak berwujud, maksudnya adalah jasa berbeda dengan barang, bila barang merupakan suatu objek, alat, atau benda, maka jasa adalah suatu perbuatan, tindakan, pengalaman, proses, kinerja (performance), atau usaha. Oleh sebab itu, jasa tidak dapat dilihat, dirasa, dicium, didengar, atau diraba sebelum dibeli atau dikonsumsi. (2) Insperability (tidak dapat dipisahkan), barang biasanya diproduksi, kemudian dijual, lalu dikonsumsi. Sedangkan jasa pada umumnya dijual terlebih dahulu, baru kemudian diproduksi dan dikonsumsi pada waktu dan tempat yang sama. Ketiga, Variability (berubah-ubah), jasa bersifat sangat variabel karena merupakan non-standardized output, artinya banyak variasi bentuk, kualitas, dan jenis, tergantung kepada siapa, kapan, dan dimana jasa tersebut diproduksi. (3) Perishability (kurangnya daya tahan), berarti jasa tidak tahan lama dan tidak dapat disimpan. Bila permintaan bersifat konstan, kondisi ini tidak menjadi masalah, karena staf dan penyedia jasa bisa direncanakan untuk memenuhi permintaan. (4) Lack of ownership, merupakan perbedaan dasar antara jasa dan barang. Pada pembelian barang, konsumen memiliki hak penuh atas penggunaan dan manfaat produk yang dibelinya. Mereka bisa mengkonsumsi, menyimpan atau menjualnya. Di lain pihak, pada pembelian jasa, pelanggan mungkin hanya memiliki akses personal atas suatu jasa untuk jangka waktu yang terbatas (misalnya kamar hotel, bioskop, jasa penerbangan, dan pendidikan)

Layanan jasa merupakan sesuatu hal yang sangat kompleks. Kompleksitas dari jasa tersebut membuat jasa sangat sukar untuk dievaluasi. 
Ketidakberwujudan dari jasa berpengaruh pada mudah atau tidaknya jasa tersebut dievaluasi. Kualitas jasa yang sangat bersifat tangible umumnya lebih mudah dievaluasi dibandingkan kualitas jasa yang sangat ingtangible. Untuk menilai kualitas layanan, Parasuraman, Zeithaml, dan Berry (1985) memberikan suatu model yang dinamakan dengan service quality model (servqual). Model servqual meliputi analisis terhadap 5 kesenjangan yang berpengaruh terhadap kualitas jasa.

Kesenjangan pertama adalah kesenjangan antara harapan konsumen dan persepsi manajemen terhadap harapan konsumen. Menurut mereka, pihak manajer eksekutif tidak selamanya dapat memahami apa yang diharapkan oleh pelanggan akan jasa secara akurat. Kurang pahamnya pimpinan akan harapan konsumen mempengaruhi persepsinya terhadap harapan konsumen, yang pada akhirnya akan berdampak juga pada evaluasi akan kualitas jasa perusahaan.

Kesenjangan kedua adalah kesenjangan antara persepsi manajemen dengan harapan pelanggan dan spesifikasi atau standar kualitas jasa. Terkadang pihak manajemen mampu memahami harapan dari pelanggan secara tepat, namun mengalami kendala dalam menentukan spesifikasi atau standar kualitas jasa guna memenuhi harapan pelanggan tersebut. Kesenjangan atau kesenjangan antara persepsi manajemen dengan spesifikasi kualitas jasa yang dimiliki perusahaan akan mempengaruhi persepsi pelanggan akan kualitas jasa.

Kesenjangan ketiga adalah kesenjangan atau kesenjangan antara spesifikasi kualitas jasa yang sudah ditetapkan perusahaan atau penyampai jasa. Kesenjangan ini disebabkan oleh performance atau kinerja dari pegawai yang memberikan jasa. Faktor-faktor yang mempengaruhi terjadinya kesenjangan ini, diantaranya: karyawan kurang terlatih (belum menguasai tugasnya), beban kerja terlampau berlebihan, standar kinerja yang tidak dapat dipenuhi oleh karyawan, atau bahkan karyawan tidak bersedia memenuhi standar kinerja yang ditetapkan. Selain itu, mungkin pula karyawan dihadapkan pada standar yang kadang kala saling bertentangan satu sama lain (Tjiptono, 2014).

Kesenjangan keempat adalah kesenjangan atau kesenjangan antara penyampai jasa dengan komunikasi eksternal. Penyampaian iklan melalui berbagai media dan janji atau slogan yang dibuat oleh perusahaan bisa mempengaruhi harapan dari pelanggan. Harapan pelanggan akan menjadi tinggi karena didasarkan pada janji-janji perusahaan. Apabila jasa yang diberikan tidak sesuai dengan janji yang dikemukakan lewat berbagai media akan mengakibatkan persepsi pelanggan akan kualitas jasa perusahaan menjadi rendah. 
Kesenjangan kelima adalah kesenjangan antara jasa yang diharapkan dan jasa yang dipersepsikan. Kunci untuk memastikan perusahaan memiliki yang baik adalah apabila jasa yang disajikan mampu untuk memenuhi atau melebihi jasa yang diharapkan oleh pelanggan. Untuk melihat kualitas jasa dari sisi pelanggan (kesenjangan 5). Dimensidimensi dari jasa yang dapat digunakan untuk mengevaluasi kualitas jasa yang terdiri dari 10 kriteria, yaitu: (1) kemampuan mewujudkan jasa sesuai janji (reliability), (2) kemauan dan kesiapan dari karyawan untuk memberikan layanan (responsiveness); (3) keterampilan pengetahuan yang disyaratkan untuk memberikan layanan (competence); (4) kedekatan dan kemudahan dalam interaksi (access); (5) sikap sopan, hormat dan keramahtamahan dari contact personal (courtesy); (6) kemampuan berkomunikasi dengan pelanggan (communication); (7) dapat dipercaya dan jujur (credibility); (8) aman, terjamin serta legal (security); (9) memahami kebutuhan dan keinginan pelanggan (understanding/knowing the customer); (10) wujud fisik dari layanan seperti fasilitas, peralatan, gedung (tangible).

Kesepuluh dimensi karakteristik dari jasa tersebut akhirnya dimodifikasi menjadi 5 dimensi, yaitu keterandalan, ketanggapan, jaminan, empati dan kemampuan untuk diindera (realibility, responsiveness, assurance, empathy, dan tangible) (Zeithaml, Bitner, \& Gremler, 2018). Lovelock (2011) mengembangkan model 5 kesenjangan servqual menjadi 7 kesenjangan, yaitu: (1) the knowing gap, kesenjangan ini terjadi karena adanya perbedaan antara pengetahuan penyedia layanan jasa akan harapan pelanggan dan harapan sebenarnya dari pelanggan, (2) the standars gap, kesenjangan ini terjadi karena adanya perbedaan antara persepsi manajemen akan harapan pelanggan dengan standar kualitas penyampaian jasa yang ditetapkan, (3) the delivery gap, kesenjangan ini terjadi karena adanya perbedaan antara spesifikasi standar penyampaian jasa dan kinerja sebenarnya dari jasa penyedia jasa terhadap standar ini, (4) the delivery communication gap, kesenjangan ini dikarenakan adanya perbedaan antara iklan dan promosi yang dilakukan perusahaan berkaitan dengan features, perfonmance, serta level kualitas layanan sebenarnya yang mampu disajikan oleh perusahaan, (5) the perceptions gap, merupakan perbedaan antara layanan sebenarnya yang diberikan dan apa yang dipersepsikan oleh pelanggan akan diterima, (6) the interpretation gap, gap ini terjadi karena adanya perbedaan penilaian antara kualitas pelayanan yang dijanjikan perusahaan melalui iklan dan promosi dan kualitas layanan yang dipikirkan oleh pelanggan akan diterima dengan adanya iklan dan promosi tersebut, 
dan (7) the service gap, merupakan perbedaan antara harapan pelanggan akan kualitas layanan dan persepsi pelanggan akan layanan aynag sebenarnya diterima atau dirasakan.

Tingkat kepuasan pelanggan adalah perasaan senang atau kekecewaan seseorang setelah membandingkan kinerja atau hasil yang dirasakan dibandingkan dengan harapannya. Jika kinerja melebihi harapan, pelanggan akan senang atau puas (Kotler dan Keller, 2012). Kepuasan pelanggan timbul dari adanya respon emosional terhadap produk (jasa) yang digunakan, khususunya ketika pelanggan membandingkan kinerja yang ia rasakan dibandingkan dengan harapannya (Hasan, 2008). Hasan selanjutnya menyatakan bahwa kepuasan yang diperoleh pelanggan merupakan fungsi dasar dari sejumlah nilai produk (kinerja) yang dipersepsikan oleh pelanggan dibanding dengan harapan pelanggan sebelum mengkonsumsi (menggunakan) produk atau jasa tersebut.

Kepuasan atau $\mathrm{f}$ merupakan harapan terhadap produk atau jasa dibagi kinerja produk atau jasa yang dirasakan. Dalam persamaan ini, kecenderungan customer akan menyatakan kepuasan dalam berbagai level sebagai berikut: (1) jika customer mempersepsikan bahwakinerja produk yang dinikmatinya lebih besar atau lebih tinggi dari yang diharapkan oleh customer, maka customer akan menyatakan bahwa mereka akan sangat puas (kinerja $>$ harapan berarti sangat puas), (2) apabila customer mempersepsikan bahwa kinerja produk atau jasa yang dinikmati atau dirasakannya sama dengan yang diharapkan oleh customer, maka customer akan menyatakan bahwa mereka puas (kinerja $=$ harapan berarti puas). (3) apabila customer mempersepsikan bahwa kinerja produk yang dinikmatinya lebih kecil atau lebih rendah dari apa yang diharapkan oleh customer, maka customer akan menyatakan bahwa mereka kecewa (kinerja $<$ harapan artinya kecewa).

Zeithaml dan Bitner menyatakan bahwa kualitas jasa merupakan faktor evaluasi yang merefleksikan persepsi dengan customer akan dimensi-dimensi dari jasa, sedangkan kepuasan customer dipengaruhi oleh persepsi customer akan kualitas jasa, kualitas barang, harga faktor situasi, dan faktor individu (Zeithaml dan Bitner, 2018). Dalam aspek pemasaran jasa, aspek manusia atau pegawai memiliki kontribusi dalam pembentukan kepuasan customer. Customer tidak sekedar mengharapkan mutu dari jasa tersebut tetapi juga melihat cara dan sikap pemberi jasa dalam memberikan layanan.

Hal tersebut menunjukan bahwa dalam membentuk kepuasan customer maka hubungan atau relasi antara penyedia dan pemakai jasa merupakan suatu hal yang penting yang tidak bisa diabaikan begitu saja. Hubungan keterlibatan customer dalam perusahaan akan 
mempengaruhi kepuasan dari customer tersebut. Hubungan tersebut akan berdampak positif apabila perusahaan memberikan layanan yang baik, tapi jika sebaliknya maka para customer yang dekat dengan perusahaan tersebut akan menjadi sumber informasi dalam menyuarakan ketidakpuasan kepada customer lain (Goodman et.al., 1995).

Tjiptono menyatakan bahwa apabila terjadi ketidakpuasan customer akan pelayanan yang diberikan, paling tidak terdapat empat kemungkinan respon customer. Respon yang pertama customer tidak melakukan apa-apa, maksudnya customer tidak menyampaikan kompainnya kepada siapapun, namun kebanyakan di anatar mereka praktis sudah beralih ke pemasok atau penyedia layanan lain (Tjiptono, 2005).

Respon yang kedua customer berhenti membeli (menggunakan) jasa dari perusahaan yang bersangkutan atau menyampaikan negative/bad word-of mouth kepada keluarga, rekan sejawat, maupun orang dekat lainnya. Informasi negatif semacam ini biasanya mengalir cepat dan berdampak negatif pada citra peusahaan maupun sikap customer terhadap penyedia jasa/produk. Akibatnya bisa kehilangan banyak customer.

Respon yang ketiga customer menyampaikan komplain secara langsung dan/ atau meminta kompensasi kepada perusahaan atau penyalurnya. Hal ini merupakan keuntungan bagi perusahaan mendapatkan umpan balik berharga dari berbagai komplain yang disampaikan. Bila komplain itu ditangani secara efektif dan memuaskan, customer yang semula tidak puas bisa berubah menjadi puas dan akan tetap menggunakan layanan dari perusahaan.

Respon yang terakhir, adalah customer mengadu lewat media massa, mengadu ke lembaga konsumen atau instansi pemerintah terkait, dan atau menunut penyedia layanan secara hukum. Kepuasan konsumen dihasilkan dari proses perbandingan antara kinerja yang dirasakan dengan harapannya, yang menghasilkan disconfirmation paradigm.

Fornell dalam temuannya menyebutkan bahwa kepuasan konsumen secara menyeluruh adalah hasil evaluasi dari pengalaman konsumsi sekarang yang berasal dari keandalan dan standarisasi pelayanan. Di samping itu, kepuasan konsumen secara menyeluruh adalah hasil perbandingan tingkat kepuasan dari usaha yang sejenis. Kepuasan konsumen secara menyeluruh diukur berdasarkan pengalaman dengan indikator harapan secara keseluruhan, harapan yang berhubungan dengan kebiasaan, dan harapan yang berhubungan dengan keterandalan jasa tersebut (Fornell et al., 1996).

Oliver dan De Sarbo memandang tingkat kepuasan (satisfaction) timbul karena adanya 
suatu transaksi khusus antara produsen dengan konsumen yang merupakan kondisi psikologis yang dihasilkan ketika faktor emosi mendorong harapan (expectations) dan disesuaikan dengan pengalaman mengkonsumsi sebelumnya (perception) (Oliver \& De Sarbo, 1988).

Berbicara mengenai evaluasi mengenai persepsi masyarakat secara umum tentang museum. Sebagian besar dari mereka masih beranggapan bahwa museum tak ubahnya seperti toko atau gudang yang menyimpan barang-barang. Tak semua orang memahami bahwa ada nilai-nilai yang perlu dipelajari dari benda-benda yang terpajang di museum tersebut (Mey \& Mohamed, 2010). Dimana benda-benda tersebut sangat memiliki makna yang dalam dalam meningkatkan kebanggaan kita sebagai bangsa dan mengembangkan identitas sebagai sebuah bangsa yang digdaya dimata bangsa lain (Priyatmoko, 2016).

Berbagai macam artefak yang ditampilkan di museum, sesungguhnya mengkomunikasikan adanya keanekaragaman budaya di tanah air sekaligus menghadirkan wajah yang unik antara satu daerah dengan daerah lain, disaat dunia kini mencoba menjerumuskan pada keseragaman dalam karya rupa bangunan dan teknologi.

Manajemen komunikasi sejatinya juga berperan dalam mengabarkan kepada masyarakat umum mengenai kekhasan yang dimiliki satu museum dengan museum yang lain. Manajemen komunikasi tidak hanya mengurusi segala hal yang berkait dengan urusan internal yang ada di museum tersebut, ditinjau dari komunikasi organisasi, namun juga mengabarkan keunggulan-keunggulan yang dimiliki oleh museum tersebut termasuk unsurunsur kultural di dalamnya (Palumbo, Dominici, \& Basile, 2013). Adakalanya kampanye pun dilakukan dengan mengemukakan unsurunsur apa saja yang dapat menjadi nilai jual dan keunggulan serta daya tarik dari museum tersebut, yang dapat dijual atau dipamerkan kepada pengunjungnya.

Adapun unsur-unsur yang perlu diperhatikan dalam mengelola museum agar dapat menarik perhatian pengunjung. Bahan material yang mendukung informasi awal dan singkat mengenai museum itu sendiri. Hal ini meliputi flyer, pamphlet, leaflet, katalog dan bulletin atau majalah internal museum itu sendiri. Kedua, manajemen waktu kunjungan yang meliputi jadwal buka tutup museum, registrasi atau pembayaran uang tiket museum, jika ada, dan buku tamu serta buku isian yang dapat mengakomodir kesan dan saran dari pengunjung museum. Ketiga adalah rancang bangun gedung baik itu desain interior maupun eksteriornya. Hal ini juga meliputi penataan letak gedung, ruang display dan penataan artefak yang membuat nyaman pengunjung dan informatif. Jangan sampai ada barang-barang 
yang bernilai, yang mudah tersenggol atau mudah disentuh oleh pengunjung, yang pada akhirnya dikhawatirkan akan merusak barang tersebut. Macam serta variasi program yang diselenggarakan oleh museum. Hal tersebut juga dapat dikatakan penting, mengingat jika tidak ada event yang dilakukan, maka museum tak ubahnya hanyalah menjadi tempat yang mati yang hanya menyimpan koleksi-koleksi benda bersejarah yang pada akhirnya calon pengunjung niscaya akan tidak lagi tertarik untuk berkunjung ke tempat ini. Program yang berupa event ini dapat dilakukan seperti mengadakan talk show bekerja sama televisi lokal/nasional, pertunjukan kesenian daerah, atau bahkan pentas band. Terakhir, fasilitas yang disediakan untuk para pengunjung yang ingin bersantai, seperti penyediaan tempat souvenir, kantin atau tempat makan dan ruang untuk bersantai sejenak untuk melepas lelah setelah berjalan lama mengitari museum. Dapat juga disediakan tempat untuk mengakses internet atau ruang display digital yang dapat digunakan oleh para pengunjung, untuk dapat menggali lebih jauh mengenai apa yang telah dipelajarinya dari museum tersebut.

Berdasarkan uraian diatas maka penelitian ini bertujuan untuk mengetahui seberapa besar pengaruh manajemen komunikasi yang terdiri dari pemberian layanan informasi nilai kebangsaan, pemeliharaan komunikasi yang baik antara petugas dan pengunjung museum, dan pelaksanaan etiket dan tata krama dalam melayani pengunjung museum terhadap kepuasan para pengunjung pada salah satu museum sejarah perjuangan di Kota Bandung.

\section{METODE PENELITIAN}

Metode penelitian yang digunakan dalam penelitian ini dengan metode kuantitatif, menggunakan survei eksplanatori yang mencoba untuk menghubungkan di antara variabel-variabel yang bertujuan meneliti sejauh mana variasi pada satu faktor berkaitan dengan variasi pada faktor lain (Rakhmat, 2012). Teknik pengumpulan data yang digunakan adalah kuesioner. Ukuran sampel penelitian ini adalah sebanyak 150 pengunjung. Peneliti menggunakan teknik sampel acak sederhana dari populasi yang terdiri dari pengunjung yang datang ke Museum Sejarah di Kota Bandung, periode pekan pertama yakni antara tanggal 5 sampai dengan tanggal 17 Agustus 2019.

\section{HASIL DAN PEMBAHASAN}

Untuk mengetahui pengaruh dari manajemen komunikasi yang terdiri dari tiga variabel yakni variabel melayani informasi yang berkaitan dengan sejarah dan nasionalisme $\left(\mathrm{X}_{1}\right)$, variabel memelihara komunikasi yang baik antara petugas dan pengunjung museum $\left(\mathrm{X}_{2}\right)$, 
variabel menerapkan perilaku etis /etiket dan etika dalam melayani pengunjung museum $\left(\mathrm{X}_{3}\right)$ terhadap kepuasan pengunjung (Y) di salah satu museum sejarah di Bandung digunakan analisis jalur (path).

Sebelum melihat pengaruh manajemen museum terhadap kepuasan pengunjung, pertama data yang terkumpul adalah dalam bentuk ordinal sehingga untuk keperluan pengolahan data, data tersebut ditranspormasi ke dalam data interval melalui Method of Successive Interval (MSI) dengan hasil disajikan pada lampiran. Data yang telah berbentuk interval kemudian dikelompokkan per variabel dengan cara menjumlahkan skornya, sehingga diperoleh skor $\mathrm{X}_{1}, \mathrm{X}_{2}, \mathrm{X}_{3}$ dan $\mathrm{Y}$ yang kemudian akan dianalisis lebih lanjut.

Untuk memperoleh koefisien jalur, pertama-tama kita mencari koefisien korelasi di antara variabel bebas.

$$
\begin{aligned}
& \mathrm{X} 1 \quad \mathrm{X} 2 \quad \mathrm{X} 3 \\
& \mathrm{R}=\mathrm{X} \begin{array}{l}
\mathrm{X} 1 \\
\mathrm{X} 2
\end{array}\left[\begin{array}{lll}
1,000 & 0,696 & 0,230 \\
0,696 & 1,000 & 0,226 \\
0,230 & 0,226 & 1,000
\end{array}\right]
\end{aligned}
$$

Adapun hasil proses perhitungan di atas sehingga menghasilkan nilai jalur sebagai berikut:

Untuk memperoleh koefisien jalur, maka matriks invers korelasi dikalikan dengan matriks korelasi antar variabel bebas $\mathrm{X}$ dengan variabel terikat Y, sebagai berikut:

$$
\operatorname{PYX}_{1}=\left[\begin{array}{ccc}
1,963 & -1,333 & -0,149 \\
-1,333 & 1,960 & -0,138 \\
\text { PYX }_{3} & & \\
-0,149 & -0,138 & 1,065
\end{array}\right] \times\left[\begin{array}{l}
0,588 \\
0,473 \\
0,683
\end{array}\right]
$$

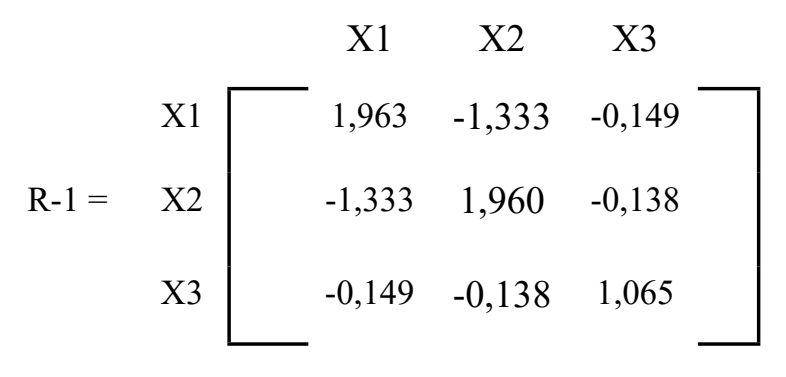

Selanjutnya dicari matriks korelasi antara variabel bebas $\mathrm{X}$ dengan $\mathrm{Y}$ :

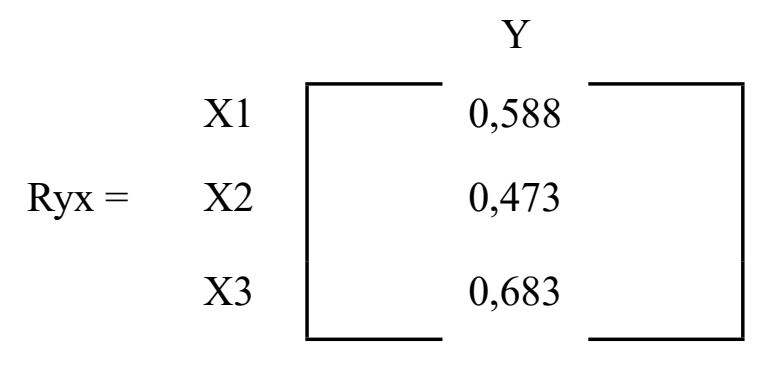

$\begin{array}{ll}\operatorname{PYX}_{1} & 0,423 \\ \mathrm{PYX}_{2} & 0,048 \\ \mathrm{PYX}_{3} & 0,575\end{array}$

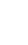




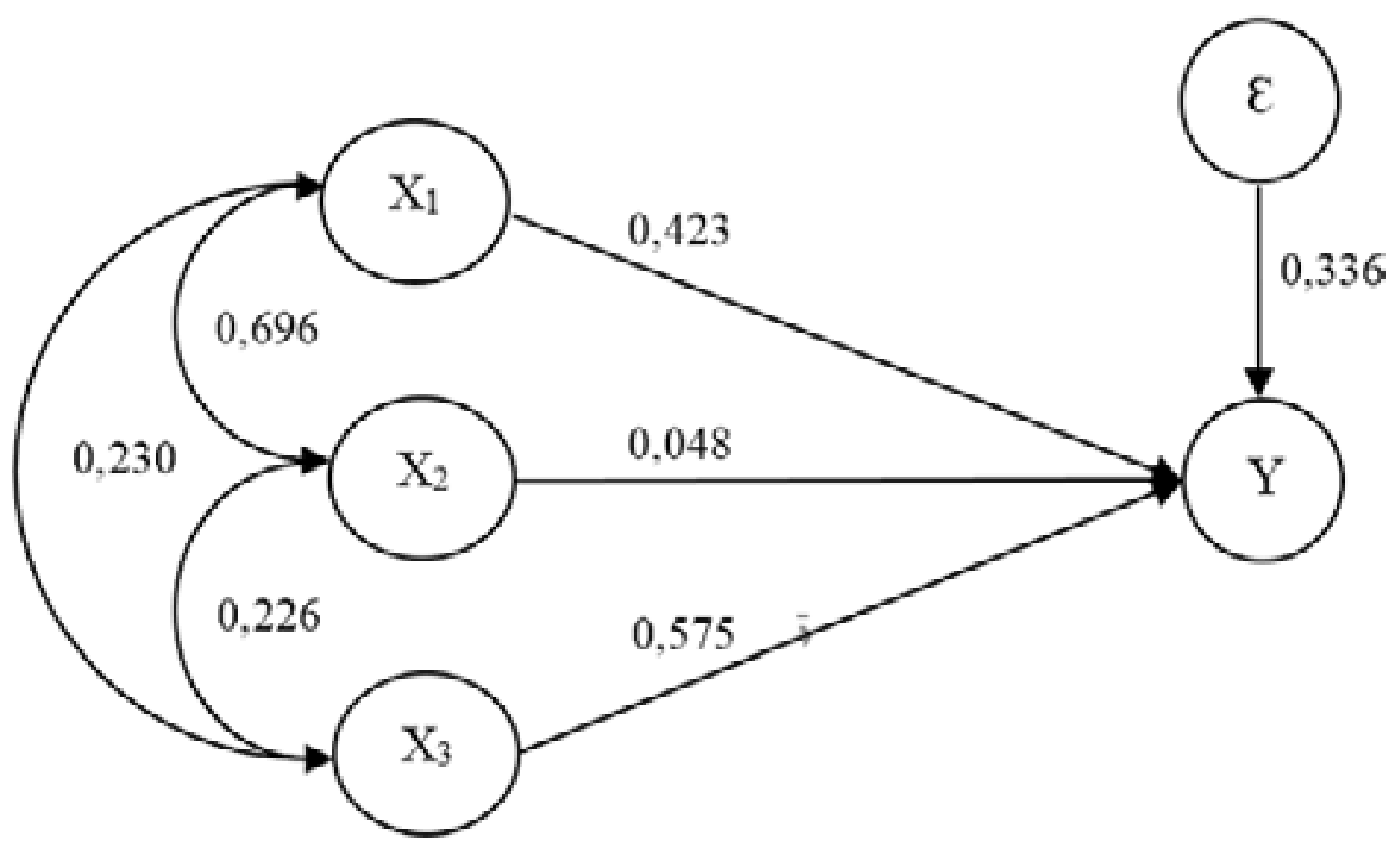

Sumber: Data Penelitian, 2019.

Gambar 1 Bagan Jalur Variabel X1 sampai X3 terhadap Variabel Y (Koefisien Jalur dan Koefisien Korelasi)

Koefisien jalur dan koefisien korelasi yang telah diperoleh tersebut jika disajikan pada bagan jalur adalah sebagai berikut:

Setelah koefisien jalur diperoleh, maka besar pengaruh variabel $X_{1}$, variabel $X_{2}$, variabel $\mathrm{X}_{3}$, secara bersama-sama terhadap variabel $\mathrm{Y}$ dapat ditentukan dari hasil perkalian koefisien jalur terhadap matriks korelasi antara variabel sebab $\mathrm{X}$ dengan variabel akibat $\mathrm{Y}$.

$$
\mathrm{R}^{2} \mathrm{Y}(\mathrm{x} 1 \times 2 \times 3)=\left[\begin{array}{lll}
0,423 & 0,048 & 0,575
\end{array}\right] \times\left[\begin{array}{c}
0,588 \\
0,473 \\
0,683
\end{array}\right]
$$

Sedangkan besar koefisien jalur untuk variabel lain di luar variabel manajemen komunikasi ditentukan melalui rumus:

$$
\begin{aligned}
P_{Z \varepsilon} & =\sqrt{1-R_{Y(X 1, X 2, X 3, X 4, X 5, X 6, X 7)}^{2}} \\
& =\sqrt{1-0,664} \\
& =0,580
\end{aligned}
$$

Manajemen komunikasi yang terdiri dari 3 variabel secara bersama-sama mempengaruhi kepuasan pengunjung sebesar $64,4 \%$ dan sisanya sebesar $(0,580)^{2}=0,336 \times 100 \%=$ $33,6 \%$. dipengaruhi faktor lain yang tidak masuk ke dalam penelitian. Jika ditampilkan dalam bentuk diagram jalur maka dapat dilihat pada diagram jalur sebagai berikut ini. 


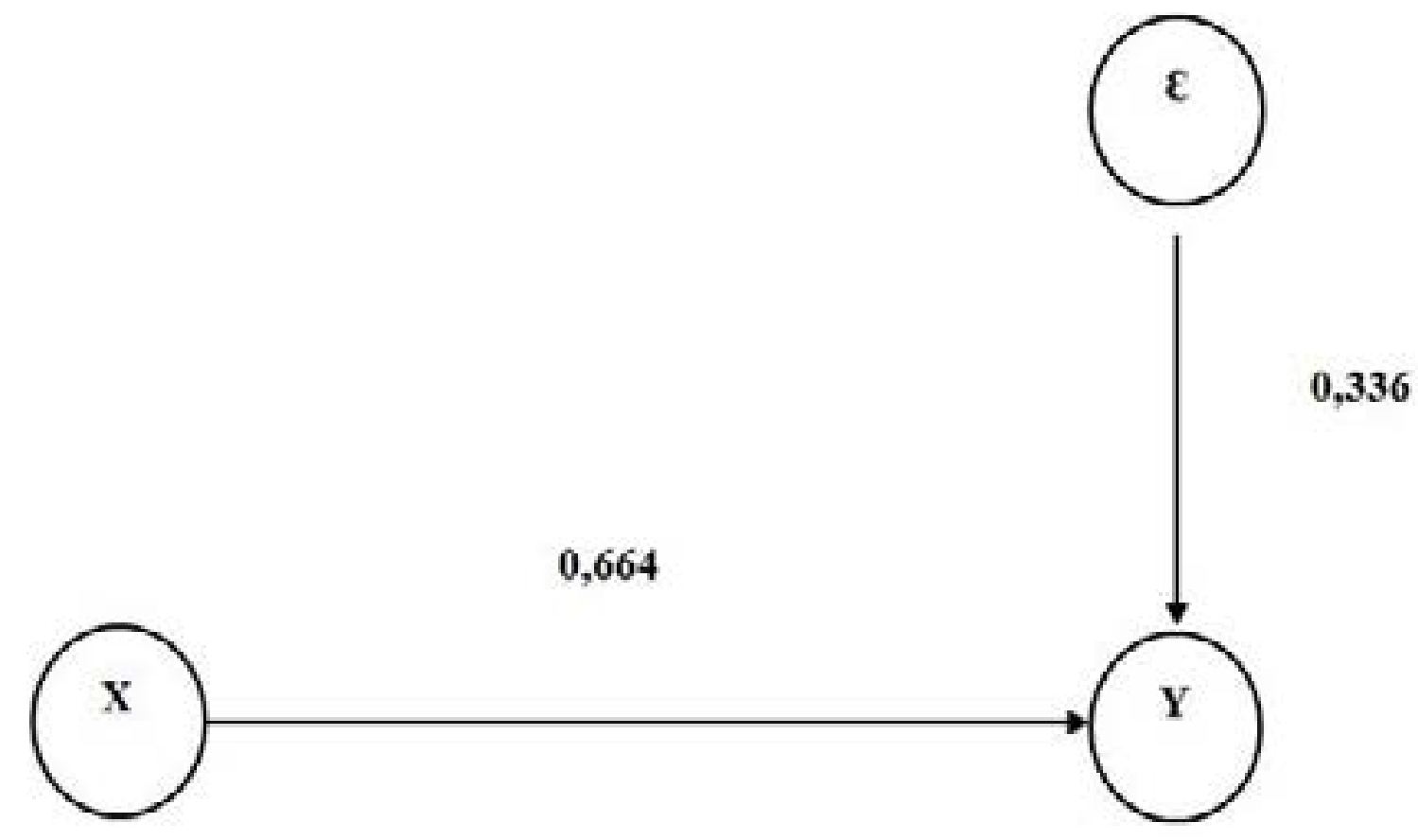

Sumber: Data Penelitian, 2019.

\section{Gambar 2 Diagram Jalur Penelitian}

Berdasarkan hasil penelitian, diperoleh pengaruh secara bersama-sama (simultan) dari variabel manajemen komunikasi terhadap kepuasan pengunjung. Untuk melihat lebih jauh tentang besar pengaruh langsung dan tidak langsung dari masing-masing variabel bebas terhadap variabel terikat, berikut disajikan rincian pengaruh langsung dan tidak langsungnya.
Variabel manajemen komunikasi dalam melayani informasi mengenai sejarah dan nilainilai nasionalisme $\left(\mathrm{X}_{1}\right)$ memberikan pengaruh terhadap kepuasan pengunjung (Y) dengan total pengaruh sebesar $24,9 \%$, terdiri atas pengaruh langsung sebesar $17,86 \%$ dan total pengaruh tidak langsung sebesar 7,00\%. Indikator yang membentuk dimensi mengabdi kepada kepentingan umum yaitu: (1) memberikan

Tabel 1 Pengaruh Langsung dan Tidak Langsung terhadap Y

\begin{tabular}{cccccccc}
\hline Variabel & $\begin{array}{c}\text { Koefisien } \\
\text { Jalur }\end{array}$ & $\begin{array}{c}\text { Pengaruh } \\
\text { Langsung } \\
\mathbf{( \% )}\end{array}$ & $\begin{array}{c}\text { Pengaruh tidak langsung (melalui), } \\
\text { dalam \% }\end{array}$ & $\begin{array}{c}\text { Pengaruh } \\
\text { Tidak } \\
\text { Langsung } \\
\mathbf{( \% )}\end{array}$ & $\begin{array}{c}\text { Total } \\
\text { Pengaruh } \\
\mathbf{( \% )}\end{array}$ \\
\cline { 3 - 6 } & & & $\mathrm{X} 1$ & $\mathrm{X} 2$ & $\mathrm{X} 3$ & & \\
\hline $\mathbf{X 1}$ & 0,423 & 17,86 & - & 1,42 & 5,58 & 7,00 & 24,9 \\
\hline $\mathbf{X 2}$ & 0,048 & 0,23 & 1,42 & - & 0,63 & 2,05 & 2,3 \\
\hline $\mathbf{X 3}$ & 0,575 & 33,05 & 5,58 & 0,63 & - & 6,21 & 39,3 \\
\hline & \multicolumn{7}{c}{ Total Pengaruh } \\
\hline
\end{tabular}


pengetahuan atau pemahaman tentang sejarah diplomasi Indonesia, (2) memberikan pemahaman atau pengetahuan tentang nilainilai kemerdekaan dan kesetaraan, dan (3) memberikan pemahaman atau pengetahuan tentang cinta tanah air dan sikap nasionalisme.

Variabel manajemen komunikasi dalam memelihara komunikasi yang baik antara petugas dan pengunjung museum $\left(\mathrm{X}_{2}\right)$ memberikan pengaruh terhadap variabel kepuasan pengunjung (Y) dengan total pengaruh sebesar $2,3 \%$, terdiri atas pengaruh langsung sebesar $0,23 \%$ dan total pengaruh tidak langsung sebesar 2,05\%. Indikator yang membentuk dimensi memelihara komunikasi yang baik yaitu: (4) berkomunikasi atau menjelaskan dengan bahasa yang mudah di mengerti, (5) berkomunikasi atau menjelaskan dengan bahasa Indonesia yang baik dan benar, dan (6) berbusana dengan rapih dan sopan.

Variabel manajemen komunikasi dalam menitikberatkan moral dan tingkah laku $\left(\mathrm{X}_{3}\right)$ memberikan pengaruh terhadap variabel kepuasan pengunjung (Y) dengan total pengaruh sebesar $39,3 \%$, terdiri atas pengaruh langsung sebesar $33,05 \%$ dan total pengaruh tidak langsung sebesar $6,21 \%$. Indikator yang membentuk dimensi menitikberatkan moral dan tingkah laku yaitu: (7) pemandu/ pengelola museum bersikap santun terhadap pengunjung, (8) pemandu/pengelola museum bersikap murah senyum terhadap pengunjung, (9) pemandu/pengelola museum bersikap ramah (hangat) terhadap pengunjung, dan (10) pemandu/pengelola museum bersikap jujur terhadap pengunjung.

Adapun pengujian hipotesisnya adalah sebagai berikut; pertama, uji simultan (keseluruhannya) :

$$
\begin{aligned}
\mathrm{H}_{0}= & \mathrm{P}_{\mathrm{YX} 1}=\mathrm{P}_{\mathrm{YX} 2}=\mathrm{P}_{\mathrm{YX} 3}=0 \\
\mathrm{H}_{1}= & \text { sekurang-kurangnya ada sebuah } \\
\mathrm{P}_{\mathrm{Yxi}} & \neq 0, \mathrm{i}=1,2,3
\end{aligned}
$$

Kriteria uji, Tolak $\mathrm{H}_{0}$ jika $\mathrm{F}$ hitung $\geq \mathrm{F}$ tabel, terima $\mathrm{H}_{1}$ dalam hal lainnya. Dimana $\mathrm{F}$

\section{Tabel 2 Uji F}

\begin{tabular}{|c|l|c|c|c|c|c|}
\hline \multicolumn{7}{|c|}{ ANOVA $^{\mathrm{b}}$} \\
\hline Model & & Sum of Squares & $\mathrm{df}$ & Mean Square & F & Sig \\
\hline 1 & Regression & 3177,233 & 3 & 1059,078 & 23,715 &, $000^{\mathrm{a}}$ \\
& Residual & 1607,686 & 36 & 44,658 & & \\
& Total & 4784,919 & 39 & & & \\
\hline
\end{tabular}

a. Predictors: (Constant), Variabel X3, Variabel X2, Variabel X1

b. Dependent Variabel: Kepuasan Pengunjung (Y) 


\section{Tabel 3 Uji t}

\begin{tabular}{|l|l|c|c|c|r|r|}
\hline \multicolumn{2}{|c|}{} & \multicolumn{2}{|c|}{$\begin{array}{c}\text { Unstandarized } \\
\text { Coefficients }\end{array}$} & $\begin{array}{c}\text { Standarized } \\
\text { Coefficients }\end{array}$ & & \\
\cline { 3 - 5 } \multicolumn{2}{|c|}{ Model } & \multicolumn{1}{|c|}{ B } & Std. Error & Beta & \multicolumn{1}{c|}{ t } & Sig \\
\cline { 2 - 5 } 1 & (Constant) & 6,304 & 5,464 & & 1,154 &, 256 \\
& Variabel X1 & 1,810 &, 580 &, 423 & 3,123 &, 004 \\
& Variabel X2 &, 217 &, 609 &, 048 &, 357 &, 723 \\
& Variabel X3 & 2,032 &, 352 &, 575 & 5,766 &, 000 \\
\hline
\end{tabular}

a. Dependent Variabel: Kepuasan Pengunjung (Y)

Sumber : Hasil Output SPSS Versi 20

tabel diperoleh dari tabel distribusi $\mathrm{F}$ dengan $\alpha=5 \%$ dan derajat bebas $\mathrm{db}_{1}=\mathrm{k}$, dan $\mathrm{db}_{2}=$ $\mathrm{n}-\mathrm{k}-1$. Berdasarkan formula tersebut, dengan bantuan Software SPSS maka diperoleh hasil sebagai berikut :

Uji statistik di atas mengikuti distribusi $F$ dengan $\alpha=5 \%$, derajat kebebasan $\mathrm{db}_{1}=3$, dan $\mathrm{db}_{2}=40-3-1=36$, diperoleh $\mathrm{F}$ tabel $=2,866$. Dari hasil di atas dapat dilihat bahwa F hitung $>$ F tabel $(23,715>2,866)$ sehingga sesuai dengan kriteria uji simultan adalah tolak $\mathrm{H}_{0}$, artinya manajemen komunikasi dalam melayani informasi sejarah dan nasionalisme $\left(X_{1}\right)$, manajemen komunikasi dalam memelihara komunikasi yang baik $\left(\mathrm{X}_{2}\right)$, manajemen komunikasi dalam menitikberatkan moral dan tingkah laku $\left(\mathrm{X}_{3}\right)$ secara bersama-sama berpengaruh terhadap kepuasan pengunjung (Y) di museum sejarah Bandung. Dikarenakan $\mathrm{H}_{1}$ diterima, maka pengujian dapat dilanjutkan pada pengujian hipotesis selanjutnya secara parsial.

Kedua adalah uji parsial/individu. Setelah melakukan uji simultan dengan hasil yang signifikan, maka selanjutnya dilakukan uji parsial untuk melihat variabel bebas mana saja yang berpengaruh terhadap kepuasan pengunjung (Y). Kriteria uji: Tolak $\mathrm{H}_{0}$ jika $\mathrm{t}$ hitung $>\mathrm{t}$ tabel $\left(t_{\alpha ; n-k-1}\right)$. Adapun hasil dari proses perhitungan dengan mempergunakan formula tersebut yang dibantu dengan software SPSS, maka terlihat tabel sebagai berikut :

Dari tabel output di atas dapat kita ketahui bahwa hasil pengujian hipotesis secara parsial (individual) manajemen komunikasi dalam memberi informasi mengenai sejarah dan nasionalisme $\left(\mathrm{X}_{1}\right)$, manajemen komunikasi dalam memelihara komunikasi yang baik $\left(\mathrm{X}_{2}\right)$, manajemen komunikasi dalam menitikberatkan moral dan tingkah laku $\left(\mathrm{X}_{3}\right)$.

Pertama adalah pengaruh variabel $\mathrm{x}_{1}$ terhadap variabel kepuasan pengunjung (Y). 
Bentuk Hipotesisnya adalah sebagai berikut :

$\mathrm{H}_{0}: \operatorname{Pyx}_{1}=0$, Artinya manajemen komunikasi dalam melayani informasi mengenai sejarah dan nasionalisme $\left(\mathrm{X}_{1}\right)$ tidak berpengaruh signifikan terhadap kepuasan pengunjung $(\mathrm{Y})$ di museum sejarah di Bandung

$\mathrm{H}_{1}: \mathrm{Pyx}_{1} \neq 0$, Artinya manajemen komunikasi dalam melayani informasi mengenai sejarah dan nasionalisme $\left(\mathrm{X}_{1}\right)$ berpengaruh signifikan terhadap kepuasan pengunjung (Y) di museum sejarah di Bandung

Berdasarkan tabel 3 hasil output SPSS atas, diperoleh t-hitung untuk variabel $\mathrm{X}_{1}$ sebesar 3,123, dengan t-tabel dengan $\alpha=5 \%$ dan derajat kebebasan n-k-1 yaitu 40-3-1 = 36 maka diperoleh hasil t-tabel sebesar 2,028, dari hasil tersebut diketahui bahwa t-hitung lebih besar dari t-tabel $(3,123>2,028)$ maka $\mathrm{H}_{0}$ ditolak atau $\mathrm{H}_{1}$ diterima, artinya variabel manajemen komunikasi dalam melayani informasi mengenai sejarah dan nasionalisme $\left(\mathrm{X}_{1}\right)$ berpengaruh signifikan terhadap kepuasan pengunjung (Y) di museum Sejarah Bandung.

Kedua adalah pengaruh variabel $\mathrm{x}_{2}$ terhadap variabel kepuasan pengunjung (y). Bentuk hipotesis adalah sebagai berikut :

$\mathrm{H}_{0}: \mathrm{Pyx}_{2}=0$, Artinya manajemen komunikasi dalam memelihara komunikasi yang baik $\left(\mathrm{X}_{2}\right)$ tidak berpengaruh signifikan terhadap kepuasan pengunjung (Y) di museum Sejarah Bandung
$\mathrm{H}_{1}: \mathrm{Pyx}_{2} \neq 0$, Artinya manajemen komunikasi dalam memelihara komunikasi yang baik $\left(\mathrm{X}_{2}\right)$ berpengaruh signifikan terhadap kepuasan pengunjung (Y) di museum Sejarah Bandung

Berdasarkan tabel 3 hasil output SPSS atas, diperoleh t-hitung untuk variabel $X_{2}$ sebesar 0,357, dengan t-tabel dengan $\alpha=5 \%$ dan derajat kebebasan n-k-1 yaitu 40-3-1 = 36 maka diperoleh hasil t-tabel sebesar 2,028, dari hasil tersebut diketahui bahwa t-hitung kurang dari t-tabel $(0,357<2,028)$ maka $\mathrm{H}_{0}$ diterima atau $\mathrm{H}_{1}$ ditolak, artinya variabel manajemen komunikasi dalam memelihara komunikasi yang baik $\left(\mathrm{X}_{2}\right)$ tidak berpengaruh signifikan terhadap kepuasan pengunjung (Y) di museum Sejarah Bandung.

Ketiga adalah pengaruh variabel $x_{3}$ terhadap variabel kepuasan pengunjung (y). Bentuk Hipotesis adalah sebagai berikut:

$$
\mathrm{H}_{0}: \mathrm{Pyx}_{3}=0 \text {, Artinya manajemen }
$$
komunikasi dalam memelihara menitikberatkan moral dan tingkah laku $\left(\mathrm{X}_{3}\right)$ tidak berpengaruh signifikan terhadap kepuasan pengunjung (Y) di museum Sejarah Bandung

$$
\mathrm{H}_{1}: \mathrm{Pyx}_{3} \neq 0 \text {, Artinya manajemen }
$$
komunikasi dalam menitik-beratkan moral dan tingkah laku $\left(\mathrm{X}_{3}\right)$ berpengaruh signifikan terhadap kepuasan pengunjung (Y) di museum Sejarah Bandung

Berdasarkan tabel 3 hasil output SPSS atas, 
diperoleh t-hitung untuk variabel $\mathrm{X}_{3}$ sebesar 5,766 , dengan t-tabel dengan $\alpha=5 \%$ dan derajat kebebasan n-k-1 yaitu 40-3-1 = 36 maka diperoleh hasil t-tabel sebesar 2,028, dari hasil tersebut diketahui bahwa t-hitung lebih besar dari t-tabel $(5,766>2,028)$ maka $\mathrm{H}_{0}$ ditolak atau $\mathrm{H}_{1}$ diterima, artinya variabel manajemen komunikasi dalam menitik-beratkan moral dan tingkah laku $\left(\mathrm{X}_{3}\right)$ berpengaruh signifikan terhadap kepuasan pengunjung (Y) di museum Sejarah Bandung.

Kontribusi manajemen komunikasi museum sejarah terhadap kepuasan pengunjung museum sebesar $66,4 \%$, besarnya kontribusi manajemen komunikasi terhadap kepuasan pengunjung museum signifikan (besar). Dimensi yang memberikan kontribusi cukup bila dibandingkan dengan dimensi-dimensi lain dari manajemen komunikasi terhadap kepuasan pengunjung.

Faktor yang perlu dihatikan dari variabel manajemen komunikasi dalam memelihara komunikasi yang baik dari pengelola/pemandu museum, antara lain: (1) berkomunikasi dengan bahasa yang mudah di mengerti, (2) berkomunikasi dengan Bahasa Indonesia yang baik dan benar, (3) berbusana/berpenampilan yang rapih dan sopan. Dengan demikian, kiranya sangat diperlukan di dalam pelaksanaan komunikasi yang baik dan efektif bagi pelaksanaan manajemen komunikasi terutama dalam memelihara komunikasi yang baik yang dilakukan oleh pengelola museum untuk menunjang kepuasan pengunjung.

Memelihara komunikasi yang baik perlu dilakukan oleh pengelola museum untuk menjalin komunikasi yang baik dan efektif, hubungan yang harmonis, tercipta saling pengertian kedua belah pihak khususnya pengunjung, menciptakan kesan, persepsi dan citra positif bagi organisasi/institusi (museum) yang diwakilinya. Hal tersebut sejalan dengan Parasuraman et.al. (1985) menyatakan bahwa komunikasi yaitu kemampuan dalam berkomunikasi untuk penyampaian pesan, informasi kepada customernya melalui berbagai media komunikasi, yaitu personal kontak, media publikasi/promosi, telepon, dan lainnya.

Salah satu yang harus diperhatikan dalam memeliharakomunikasi yang baikadalah adanya sumber informasi dan sebagai saluran informasi untuk itu harus diadakan sebuah information desk untuk melayani publik baik karyawan maupun orang-orang dari luar (pengunjung). Orang yang ditempatkan pada information desk perlu orang yang wajahnya menarik, sikapnya ramah-ramah, juga menguasai persoalanpersoalan yang bersangkutan dengan organisasi tersebut (museum).

Komunikasi merupakan faktor sangat esensial dan penting dalam melaksanakan kontak personal atau hubungan konsumen. 
Jika terjadi kesenjangan berkomunikasi, maka akan menimbulkan penilaian (persepsi) negatif terhadap kualitas jasa. Terdapat beberapa bentuk kesenjangan komunikasi yang biasa terjadi yaitu: tidak mampu memberikan informasi yang lengkap, pesan yang disampaikan tidak dipahami oleh customer, dan pihak perusahaan/ institusi tidak selalu memperhatikan secara serius dalam menanggapi keluhan atau saransaran dari para customer atau konsumennya.

Selain permasalahan di atas mungkin pengunjung merasa kurang puas terhadap pelayanan pengelola museum dalam hal interaksi dan memberikan informasi yang dibutuhkan karena pendekatan yang dilakukan kurang efektif, cenderung memperlakukan atau memberikan pelayanan yang sama (menggeneralisasi) terhadap setiap pengunjung. Pengunjung/konsumen adalah manusia yang bersifat unik, yang memiliki perasaan, keinginan, dan emosi yang tidak sama satu dengan yang lainnya. dalam interaksi pelayanan jasa tersebut tidak semua customer/konsumen dapat menerima atau bersedia menerima pelayanan yang secara seragam (standardized service). Bahkan ada customer menginginkan pelayanan perhatian secara personal (personal approach). Dalam hal ini diperlukan pemahaman atas perasaan dan kebutuhan pelayanan yang khusus oleh pihak perusahaan ketika memberikan layanan jasa terhadap customer/konsumen yang beragam tersebut.

Manajemen komunikasi dalam melayani informasi sejarah dan nasionalisme berpengaruh signifikan(besar) terhadapkepuasan pengunjung museum daripada manajemen komunikasi dalam memelihara layanan komunikasi yang baik dari petugas kepada pengunjung. Para pengunjung merasa puas terhadap pesan informasi atau pengetahuan yang diperoleh setelah berkunjung ke museum. Pengunjung mendapatkan pengetahuan dan wawasan yang baru mengenai nilai-nilai dan pelajaran sejarah diplomasi Indonesia, pemahaman tentang nilai-nilai kemerdekaan, rasa cinta tanah air dan sikap nasionalisme yang semua itu dapat meningkatkan kemampuan kognitif pengunjung menjadi lebih luas lagi.

Manajemen komunikasi dalam menitikberatkan moral dan tingkah laku berpengaruh paling signifikan (besar) dibandingkan dengan sub variabel manajemen komunikasi lainnya. itu dikarenakan para pengunjung merasa puas dengan pelayanan yang diberikan oleh pengelola museum yang bersikap dan bertingkah laku yang baik dan positif seperti santun, murah senyum, ramah, jujur sehingga dapat memberikan rasa puas dan sikap percaya pengunjung, merasa dihargai dan diperhatikan sehingga menimbulkan mencapai keuntungan atau tujuan bersama.

Hasil penelitian ini menunjukkan bahwa 
manajemen komunikasi terhadap kepuasan pengunjung terdapat sedikit perbedaan bahwa pengunjung dalam memelihara/melakukan komunikasi yang baik terhadap pengelola museum ini. Pengunjung merasa senang dan puas setelah mendapatkan penjelasan atau informasi yang jelas dan baik dari pemandu atau pengelola museum setelah menjelaskan semua hal tentang museum. Pengunjung museum merasa antusias dan seksama mendengarkan pemandu menjelaskan tentang museum tersebut. Dengan demikian, penelitian ini dapat menjawab hipotesis yang diajukan, bahwa manajemen komunikasi pada organisasi museum berpengaruh signifikan (besar) terhadap kepuasan pengunjung museum sejarah Bandung.

Dari hasil wawancara dengan beberapa pengunjung, didapatkan beberapa harapan dan masukan yang cukup bermanfaat untuk dapat memperbaiki pengelolaan museum di masa mendatang. Salah satunya adalah yakni saran agar pengelola museum seyogyanya mengkomunikasikan semua aktivitas museum sejarah ini kepada masyarakat melalui kegiatan - kegiatan seperti kampanye yang memiliki dimensi sosial.

Kampanye ini sebaiknya dilakukan dengan memanfaatkan momentum liburan, bekerja sama dengan komunitas peminat sejarah dan dinas pariwisata, untuk menghimbau masyarakat untuk lebih sering mengunjungi museum. Kampanye ini dapat dilakukan tidak hanya memanfaatkan misalnya moment Car Free Day, namun juga dapat secara proaktif dilakukan ke sekolah-sekolah dan sekaligus mendorong guru serta siswanya untuk datang ke museum.

Di samping itu, museum sebagai sebuah organisasi tentu perlu juga membangun situs web yang atraktif, agar dapat menjadi "pancingan" orang-orang untuk berkunjung ke museum bersejarah ini. Di masa kini, keberadaan internet dalam menunjang eksistensi museum adalah sebuah keniscayaan dan sudah menjadi suatu kewajiban global. Bila sebuah museum tak dapat diakses secara daring (online), maka museum tersebut akan hanya menjadi layaknya tempat menyimpan barang-barang antik saja.

Kecenderungan di masa kini, masyarakat akan melakukan penelusuran terlebih dahulu dengan mesin pencarian seperti Google sebelum berkunjung ke tempat-tempat yang dapat menarik atensinya. Selain itu juga sejalan dengan pengelolaan situs web yang lebih profesional pada museum, akan mendorong terbentuknya sebuah forum yang aktif, yang akan menjadi ajang berkomunikasi secara aktif bagi publik yang tertarik pada kegiatan permuseuman.

Saran dari responden yang lain adalah memanfaatkan museum sebagai setting dalam 
sebuah karya seperti sinema elektronika (sinetron) atau film yang bernilai edukasi, atau memanfaatkan lahan di luar museum (seperti tempat parkir) untuk ajang penampilan musik dan karya seni sendratari yang dapat memikat baik itu wisatawan asing maupun dalam negeri.

Pendapat responden lain mengatakan bahwa museum adalah sarana komunikasi yang menjelaskan segala peristiwa yang terjadi di masa lalu demi menjadi pelajaran untuk menjadi lebih baik di masa depan. Seyogyanya museum harus mencari cara agar lebih proaktif agar lebih dekat dengan kalangan anak muda. Seperti yang diketahui bahwa pemuda adalah golongan masyarakat yang penuh dinamika. Sedangkan museum kesannya adalah statis. Oleh karena itu, perlu ada kerjasama antara pengelola museum dan kelompok anak muda untuk lebih rajin dalam mengadakan ajang kreasi di sekitar museum.

Masukan dari beberapa pengunjung berkaitan dengan interior bangunan. Hendaknya gedung bagian di luar di cat lebih sering dengan menggunakan cat yang tahan lama. Interior dalam sebaiknya setiap lima tahun sekali diubah, agar tidak membosankan, penataan taman yang asri, ruang presentasi yang dilengkapi dengan multimedia yang canggih dan tempat ibadah (musholla) dan dapat menarik pengunjung untuk mengunjunginya berkali-kali dan lebih nyaman serta lebih terasa hangat.

\section{SIMPULAN}

Berdasarkan analisis data dan pembahasan yang telah dilakukan pada sebelumnya, maka penulis mengambil simpulan bahwa secara simultan (bersamasama) manajemen komunikasi yang terdiri dari tiga variabel yakni variabel melayani informasi yang berkaitan dengan sejarah dan nasionalisme, variabel memelihara komunikasi yang baik antara petugas dan pengunjung museum, variabel menerapkan perilaku etis / etiket dan etika dalam melayani pengunjung museum terhadap kepuasan pengunjung di salah satu museum sejarah di Bandung berpengaruh signifikan terhadap kepuasan pengunjung di museum Sejarah Bandung.

Sedangkan secara parsial, simpulan dari penelitian ini adalah (1) variabel manajemen komunikasi dalam melayani informasi mengenai sejarah dan nasionalisme berpengaruh signifikan terhadap kepuasan pengunjung di museum Sejarah Bandung; (2) variabel manajemen komunikasi dalam memelihara komunikasi yang baik tidak berpengaruh secara signifikan terhadap kepuasan pengunjung di museum Sejarah Bandung; (3) manajemen komunikasi dalam menitikberatkan moral dan tingkah laku berpengaruh secara signifikan terhadap kepuasan pengunjung di museum Sejarah Bandung. 
Berdasarkan temuan penelitian, saran dari penelitian ini adalah bagi pengelola Museum sejarah Bandung, untuk manajemen komunikasi dalam memelihara komunikasi yang baik tidak berpengaruh secara signifikan. Hal tersebut dikarenanya perlu upaya yang lebih baik lagi dengan meningkatkan komunikasi agar menjadi lebih interaktif, lebih efektif lagi sehingga menimbulkan saling pengertian dan kepercayaan untuk menunjang kepuasan pengunjung semakin meningkat.

Salah upaya yang bisa dilaksanakan oleh pengelola museum ini adalah dengan memilih dan menyaring pemandu yang pandai berkomunikasi dan bisa melaksanakan manajemen komunikasi yang baik yaitu membangun komunikasi dan hubungan yang baik dengan pengunjung. Aspek manajemen komunikasi yang berpengaruh signifikan dalam kepuasan pengunjung adalah menitikberatkan moral dan tingkah laku juga mengabdi kepada kepentingan umum.

Oleh karena itu, pihak museum harus mempertahankan sikap baik dan positif tersebut seperti sikap yang santun, murah senyum, ramah (bersahabat) dan jujur terhadap pengunjung itu membuat pengunjung museum menjadi nyaman dan senang berada di museum. Selain itu, juga mempertahankan fungsi museum yang sudah tercapai dengan baik yaitu untuk mendidik dan memberikan pengetahuan kepada pengunjung seperti mengajarkan tentang sejarah diplomasi Indonesia, nilai-nilai kemerdekaan atau kesetaraan dan rasa cinta tanah air dan nasionalisme terhadap negara sehingga pengunjung menjadi puas karena mendapatkan pendidikan dan pengetahuan yang baru mengenai itu semua.

Saran bagi peneliti selanjutnya adalah dengan diketahuinya pengaruh manajemen komunikasi museum sejarah di Kota Bandung terhadap kepuasan pengunjung secara signifikan, maka sisanya merupakan pengaruh dari variabel lain yang tidak diketahui. Oleh karena itu, mungkin hal tersebut bisa mendorong penelitian selanjutnya untuk meneliti variabel lain tersebut tersebut untuk diteliti lebih mendalam lagi dalam penelitian selanjutnya.

\section{DAFTAR PUSTAKA}

Chiappa, D., Giacomo, Andreu, L., \& G. Gallarza, M. (2014). Emotions and visitors' satisfaction at a museum. International Journal of Culture, Tourism and Hospitality Research, 8(4), 12.

Dirsehan, T. (2012). Analyzing museum visitor experiences and post experience dimensions using SEM. Bogazici Journal: Review of Social, Economic \& Administrative Studies, 26(1). https://doi.org/10.21773/ boun.26.1.6

Effendy, O. U. (2009). Human relations and public relations (19th ed.). Bandung: Mandar Maju.

Fitriani, I. (2018). Sejarah dan peran sosial museum. Retrieved from Direktorat Jendral 
Kebudayaan Kementrian Pendidikan dan Kebudayaan website: https://kebudayaan. kemdikbud.go.id/ditpcbm/sejarah-danperan-sosial-museum/

Fornell, C., Johnson, M. D., Anderson, E. W., Cha, J., \& Bryant, B. E. (1996). The American customer satisfaction index: nature, purpose, and findings. Journal of Marketing, 60(4), 7-18. https://doi. org/10.2307/1251898

Fuadona, F. (2016). Ini daftar museum yang ada di kota Bandung. Retrieved April 8, 2020, from Merdeka.com website: https:// bandung.merdeka.com/daftar-alamat/ ini-daftar-museum-yang-ada-di-kotabandung-160105d.html

Goodman, P. S., Fichman, M., Lerch, F. J., \& Snyder, P. R. (1995). Customer-firm relationships, involvement, and customer satisfaction. The Academy of Management Journal, 38(5), 1310-1324. https://doi. org $/ 10.2307 / 256859$

Hasan, A. (2008). Marketing (cetakan Pe). Jogyakarta: Media Pressindo.

Kotler, \& Keller. (2012). Manajemen pemasaran. edisi 12. Jakarta: Erlangga.

Lovelock, C. H., \& Wirtz, J. (2011). Services marketing people, technology, strategy (7th editio). New Jersey: Prentice Hall Inc.

Mey, L. P., \& Mohamed, B. (2010). Service quality, visitor satisfaction and behavioural intentions: Pilot study at a museum in Malaysia. Journal of Global Business and
Economics, 1(1), 226-240.

Palumbo, F., Dominici, G., \& Basile, G. (2013). Designing a mobile app for museums according to the drivers of visitor satisfaction. Recent advances in business management and marketing. Retrieved from https://papers.ssrn.com/sol3/papers. cfm?abstract_id=2298361

Parasuraman, A. P., Zeithaml, V. A., \& Berry, L. L. (1985). A conceptual model of service quality and its implications for future research. Journal of Marketing, 49(4), 4150. https://doi.org/10.2307/1251430

Priyatmoko, H. (2016). No title. Retrieved November 18, 2019, from KrJogja.com website: https://www.museumindonesia. com/cgi-bin/index.pl?section=2

Rakhmat, J. (2012). Metode penelitian komunikasi. Bandung: PT Remaja Rosdakarya.

Richard L. Oliver, \& DeSarbo, W. S. (1988). Response determinants in satisfaction judgements. The Journal of Consumer Research, 14(4), 495-507.

Tjiptono. (2005). Brand management \& strategy. Jogyakarta: ANDI.

Tjiptono, F. (2014). Pemasaran jasa-prinsip, penerapan, dan penelitian. Jogyakarta: ANDI.

Zeithaml, V., Bitner, M. J., \& Gremler, D. (2018). Services marketing integrating customer focus across the firm (7th editio). Boston: McGraw-Hill. 